Derleme Makale / Review Paper

\title{
Farklı Gıdalardan İzole Edilen Laktik Asit Bakterileri'nin Antibiyotik Direnç Profilleri
}

\author{
Ebru DEMIR ${ }^{1}$, Gülden BAŞYiĞiT KILIÇ² ${ }^{*}$, Eyüp UŞAN ${ }^{1}$ \\ ${ }^{1}$ Mehmet Akif Ersoy Üniversitesi, Fen Bilimleri Enstitüsü, Burdur \\ ${ }^{2}$ Mehmet Akif Ersoy Üniversitesi, Mühendislik-Mimarlık Fakültesi, Burdur \\ Geliş Tarihi (Received): 31.01.2018, Kabul Tarihi (Accepted): 10.07.2018 \\ $\square$ Sorumlu Yazar (Corresponding author ${ }^{\star}$ ): gkilic@mehmetakif.edu.tr \\ (C) +902482132724 且 +902482132704
}

ÖZ

Laktik asit bakterileri (LAB), insanlar ve hayvanların gastrointestinal sistemleri ve gıdalar gibi geniş bir ekolojik yelpazede doğal olarak bulunan, heterojen bir mikroorganizma grubunu temsil eder. Antibiyotikler, bakterileri inhibe edebilir veya çoğalmasını durdurabilirler. Antibiyotiklerin belirli periyotlarda ve belli dozlardaki kullanımı neticesinde hastaIıkların tedavi edildiği, ancak insan metabolizmasında yararlı faaliyetleri olan mikroorganizmaları da inaktive ettiği ve normal florayı bozduğu bilinmektedir. Hızla artan aşıı ve bilinçsiz antibiyotik kullanımı bakterilerin antibiyotiklere karşı direnç geliştirmelerine sebep olmuştur. Antibiyotik direnci sonucu hastalıkların tedavi süreleri uzamakta, ekonomik kayıplar ve mortalite oranı artmaktadır. Bu sebeple LAB' de antibiyotik direnciyle ilgili çalışmalar son yıllarda önem kazanmıştır. Bu çalışmada, antibiyotiklerin etki mekanizmalarından bahsedilmiş ve farklı fermente gıdalardan izole edilmiş LAB'nin antibiyotik direnç profillerinin belirlenmesi amacıyla yapılan çalışmalardan örnekler sunulmuştur.

Anahtar Kelimeler: Laktik asit bakterileri, antibiyotik, fermente gıda

\section{Antibiotic Resistance Profiles of Lactic Acid Bacteria Isolated from Different Foods}

\begin{abstract}
Lactic acid bacteria (LAB) represent a heterogeneous group of microorganisms that are naturally present in a wide range of ecological niches such as foods and the gastrointestinal tract of humans and animals. Antibiotics may inhibit bacteria or stop their proliferation. It is known that certain diseases can be treated with antibiotics used at certain doses and certain periods, however, it is also known that antibiotics may inactivate beneficial microorganisms for human metabolism and destroy the balance of intestinal microflora. The increasing trend in the unconscious and overuse of antibiotics resulted in the development of resistance in bacteria against antibiotics. As a result of increased bacterial resistance, the duration of disease treatment, economic losses and mortality rates are increasing. For this reason, studies on antibiotic resistance in LAB have gained importance in recent years. In this study, the mechanisms of antibiotic action are described and the studies done to determine antibiotic resistance profiles of $\mathrm{LAB}$ isolated from different fermented foods are presented.
\end{abstract}

Keywords: Lactic acid bacteria, antibiotics, fermented food 


\section{Giriş}

Laktik asit bakterileri (LAB) Gram pozitif, fakültatif anaerob, katalaz negatif, sporsuz, insanlar ve hayvanların gastrointestinal (GI) sistemleri ve gıdalar gibi geniş bir ekolojik yelpazede doğal olarak bulunan, glukozu homofermantatif ve heterofermantatif olmak üzere iki şekilde katabolize eden heterojen bir mikroorganizma grubunu temsil eder (Mathur ve Singh, 2005; Evren ve ark., 2011). LAB, Amerikan Gıda ve İlaç Dairesi tarafından uzun zaman önce Güvenli Olarak Kabul Edilen statüsüne alınmışlardır. Fermente gıdalar tüketildiğinde, insan vücuduna oldukça fazla miktarda canlı bakteri girmektedir. Bu durumda, bu bakteriler kommensal ya da patojen bakterilere taşınabilir antibiyotik direncini aktarabilirler (Hummel ve ark,. 2007). Son 10 yıl içerisinde, gıda ve yem uygulamalarında $L A B$ kültürlerinin güvenli kullanımına ilişkin artan bir ilgi söz konusudur. $\mathrm{Bu}$ ilginin sebebi, LAB'nin antibiyotik direnç genleri üzerine yapılan önemli çalışmalardır (Mathur ve Singh, 2005; Özteber, 2013).

Tüm dünyada antibiyotik direncinin oldukça tehlikeli boyutta artması; sık rastlanan enfeksiyonlara karşı tedavinin zorlaşmasına sebep olmaktadır. Özellikle pnömoni, tüberküloz gibi hastalıkların, kan zehirlenmesi ve gıda kaynaklı zehirlenmelerin tedavisi zorlaşmakta ve hatta bazı durumlarda antibiyotiklerin etkisiz kalmasından dolayı ölümler meydan gelmektedir (URL1, 2017). Antibiyotiklerin neden olduğu yan etkiler ve ilaç etkileşimleri sebebi ile hastaneye yatan hasta sayısı her geçen yıl artmakta ve bu yan etkilere bağlı olarak hastalarda morbidite oranları, hastanede yatış süresi ve tedavi maliyetlerinde artış gözlenmektedir (Founou ve ark,. 2017).

Çoklu ilaç direnci gösteren mikroorganizmaların sebep olduğu enfeksiyonlardan kaynaklı ölümlerin sayısı gün geçtikçe artmaktadır. Amerika Birleşik Devletleri (ABD) Hastalık Önleme ve Kontrol Merkezi 2014 yılı raporunda antibiyotik direncinin en önemli ikinci sağlık sorunu olduğunu belirtmiştir. Her yıl Sadece ABD'de yaklaşık 23.000 kişinin antibiyotik dirençli bakterilerin sebep olduğu enfeksiyonlardan öldüğü tahmin edilmektedir (URL2, 2010). Bu çalışmada, antibiyotik direnci, LAB'nin antibiyotik direnç profilleri ve bu konuda yapılan araştırmalardan örnekler sunulmuştur.

\section{Antibiyotik Direnci ve Antibiyotiklerin Sağlık Üze- rindeki Etkisi}

Bakterilerin antibiyotiklere gösterdiği direnç bazı mekanizmalar ile açıklanmaktadır. Pekçok antibiyotik mikroorganizmadaki bir bileşenin hedef molekülüne bağlanarak etki gösterir. Hedef molekül yapısında küçük değişikliklerin meydana gelmesi ile mikroorganizma ilacın etkinliğini azaltabilir. Bir hücreden diğerine transfer edilebilen DNA parçaları olan "dirençli plazmidlerin" üretimi ile bazı durumlarda direnç bir bakteriden diğerine geçebilir. Antibiyotiği inaktif hale getiren veya etkisini azaltan enzimler de bir hücrenin antibiyotiğe direnç kazanmasında önemli bir mekanizmadır. Bunların dışında; penetrasyonun azaltılması veya antimikrobiyal bileşiğin aktif olarak ekstrüde edilmesi ile antibiyotiğin hedef bölgeye ulaşmasının engellenmesi, hedef bölgelerin atlanması veya değişmesi, duyarlı hücrelerin daha dirençli hücre tipine dönüşerek gösterdiği adaptif cevap ve bakteri zarlarının geçirgenliğinin azalması da antibiyotik direnç mekanizmalarındandır (Eraksoy, 2011; Clewell, 2014; Sageman, 2015; Munital ve Arias, 2016).

Antibiyotik dirençliliği, doğal (intrensek), kazanılmış ve çapraz direnç olmak üzere üç şekilde oluşmaktadır. Antibiyotiğin etki edeceği bölgenin hedef bakteride bulunmaması direnç sağlar ve bu mekanizma doğal direnç olarak adlandırılır (Sharma ve ark., 2014). Kazanılmış direnç ana hücreden yavru hücreye aktarılabildiği gibi, farklı türdeki bakteriler arasında da aktarılabilir (Madhavan ve Sowmiya, 2011). Kazanılmış direncin türler arasında aktarılabilmesi, antibiyotik direnç genlerinin yayılmasına sebep olmaktadır. Çapraz direnç ise, belli bir ilaca direnç gösteren mikroorganizmaların, aynı veya benzer mekanizma ile diğer ilaçlara karşı da dirençli olmaları halidir. Çapraz direnç kromozomal veya ekstrakromozomal orjinli olabilir (Yüce, 2001). Bakterilerde direnç mekanizmasının oluşması antibiyotiğin hedefi olan molekülün değişmesi, hücre duvarı geçirgenliğinin azalması, antibiyotiğin enzimatik yıkımı ve değişik metabolik yolların gelişmesi ile ortaya çıkar (Yüce, 2001; Ong ve Shah, 2009). Tüm dünyada antibiyotik direncinin oldukça tehlikeli boyutta artması; sık rastlanan enfeksiyonlara karşı tedavinin zorlaşmasına sebep olmaktadır. Özellikle pnömoni, tüberküloz gibi hastalıkların, kan zehirlenmesi ve gıda kaynaklı zehirlenmelerin tedavisi zorlaşmakta ve hatta bazı durumlarda antibiyotiklerin etkisiz kalmasından dolayı ölümler meydan gelmektedir (Anonim, 2017). Antibiyotiklerin neden olduğu yan etkiler ve ilaç etkileşimleri sebebi ile hastaneye yatan hasta sayısı her geçen yıl artmakta ve bu yan etkilere bağlı olarak hastalarda morbidite oranları, hastanede yatış süresi ve tedavi maliyetlerinde artış gözlenmektedir.

\section{LAB'nin Antibiyotik Direnç Profilleri}

İnsan ve hayvan sağlığında kullanılan antibiyotiklere dirençli bakterilerin güvenliğini değerlendirmek için Hayvan Beslenme Bilim Kurulu tarafından 2001 yılında çeşitli kriterler oluşturulmuş ve 2003 yılında revize edilmiştir. Bu kriterler 2005 ve 2007 yıllarında Avrupa Gıda Güvenliği Otoritesi (EFSA) tarafından düzenlenen 
Hayvan Beslemede Kullanılan Ürünler ve Katkı Maddeleri (FEEDAP) panelinde iki kez güncellenmiştir. Antimikrobiyallere karşı hassas olan suşlar ile kazanılmış direnç taşıyan suşlar arasında daha güvenilir bir ayrım yapabilmek amacıyla FEEDAP teknik rehberi yayınlanmıştır. En yaygın olarak kullanılan 10 antibiyotik için direnç sınır değerleri belirlenmiştir. Bu değerler farklı LAB grup, cins ya da türleri temel alınarak tanımlanmış ve değerlendirmeye göre LAB çeşitli kategorilere ayırılmıştır. Bu grupların çoğu vankomisine doğal dirençli olarak tanımlanmıştır ve bu yüzden doğal dirençli gruplarda vankomisin antibiyotiği için MiK değerlerinin belirlenmesi gerekmemektedir. Diğer tüm antibiyotikler için EFSA raporunda belirtilen değerlerin üzerinde MiK değeri saptanması durumunda direncin genetik temelinin mutlaka araştırılması gerektiği rapor edilmiştir. Aynı raporda, MiK değerleri belirlenirken uluslarası standart metodların kullanılması önerilmiştir. Bu durum özellikle LAB için önemlidir, çünkü bu bakterilerin geliştirildiği geleneksel besiyerleri bazen antibiyotikler ile etkileşime girerek deney sonuçlarını etkilemektedir (EFSA, 2005; Clementi ve Aquilanti, 2011). EFSA 2005 yılında yayınladığı raporda doğal direnç ve kromozomal genlerdeki mutasyon sonucu oluşan direncin yatay dağılım açısından düşük bir risk oluşturduğunu ve bu tür suşların gıda tüketimi açısından kabul edilebilir olduğunu belirtmiştir. Bununla beraber, sonradan eklenen genlerle oluşan kazanılmış direnç halk sağlığı açısından tehdit oluşturmaktadır (FEEDAP, European Commision, 2005). 2007 yılında yayınlanan EFSA raporunda ise transfer edilebilir antibiyotik direnç geni taşıyan suşların hayvan yemlerinde, fermente ve probiyotik gıdalarda kullanılmaması gerektiği belirtilmiştir (EFSA, 2007).

LAB'nin antibiyotik direncini belirlemek, direnç genlerinin yerleşimini araştırmak bunların potansiyel aktarımını da aydınlatmaktadır. Genlerin dizilerinin belirlenmesi sayesinde ise diğer bakteri taksonlarında bulunan genlerle benzerlikleri araştırılabilir ve böylece genlerin orjinleri belirlenebilir (Clementi ve Aquilanti, 2011). LAB'nin antibiyotik direnci ile ilgili yapılan son çalışmalara göre antibiyotik direnç genlerini araştırmak için mikroçiplerin ya da polimeraz zincir reaksiyonu temelli tekniklerin dirençli LAB suşlarını tanımlamakta oldukça güçlü araçlar olduğu ortaya konmuştur (Clementi ve Aquilanti, 2011).

LAB'nin antimikrobiyallere duyarlılıkları kadar direnç genlerini bulundurmaları ve bu genleri aktarmaları, incelenen izolat ve antimikrobiyal maddeye göre değişmektedir (Ouoba ve ark., 2008). LAB'nin birçok türü doğal olarak plazmit taşır. Bu plazmitler çoğunlukla bakterinin metabolik aktivitesi için gerekli enzimleri kodlayan genleri taşırlar. Ancak bazı türler bu genlerin yanı sıra çeşitli antibiyotiklere karşı direnç geliştirmeyi sağlayan genleri taşıyan plazmitleri de içerirler. Bu bakteriler çeşitli gıda ürünlerinde değişik amaçlar için kullanıldığında potansiyel direnç taşıyıcı ve aktarıcı olarak iş görebilirler (Göğebakan, 2003). Lactobacilli, Pediococci, Leuconostoc ve bazı diğer Gram pozitif bakteriler doğal olarak vankomisine yüksek direnç göstermektedir (Hamilton-Miller ve Shah, 1998).

Laktobasiller, doğal olarak geniş bir antibiyotik direnci sergilemektedir (Charteris ve ark, 1998), ancak çoğu durumda antibiyotik direnci aktarılabilir türde değildir. Aktarılamaz antibiyotik dirençleri olan Lactobacillus suşları genellikle bir güvenlik endişesi oluşturmazlar. Günümüze kadar Lactobacillus türlerinde pek çok antibiyotik direnç geni saptanmıştır ve doğal olarak laktobasillerin çoğunun tetrasiklin, eritromisin ve kloramfenikol gibi protein sentezini engelleyen antibiyotiklere duyarlı olduğu belirlenmiştir. LAB'de en sık bulunan ve potansiyel olarak taşınabilir iki direnç geni; tet( $M)$ ve erm(B)'dir. Bu genleri cat genleri takip eder (Lin ve ark., 1996; Danielsen, 2002; Çataloluk ve Göğebakan, 2004). L. rhamnosus ve $L$. casei de dahil olmak üzere birçok laktobasil türü, vankomisine doğal olarak dirençli bulunmuştur (Nicas ve ark, 1989; Charteris ve ark., 1998; Swenson ve ark, 1990). Bu türler, D-alanin ile son bulan vankomisin aktivitesi için hedef öncü madde yerine D-laktat ile son bulan peptidoglukan öncüllerine sahiptir (Billot-Klein ve ark, 1994). Vankomisine dirençli laktobasillerin direnç genlerinin diğer bakterilere aktarabileceğine dair bir bulgu olmadığı için laktobasil suşlarının probiyotik olarak uzun süredir kullanımı güvenli olarak kabul edilmektedir. Tynkkynen ve ark. (1998), probiyotik suş L. rhamnosus GG'nin vankomisine direnç faktörünün enterokokların direnç özelliği ile yakından ilişkili olmadığını ve L. rhamnosus GG ve enterokoklar arasında antibiyotik direncinin transferini gözlemleyemediklerini belirtmişlerdir. Genel olarak laktobasillerde; basitrasin, sefoksitin, siprofloksasin, füzidik asit, kanamisin, gentamisin, metronidazol, nitrofurantoin, norfloksasin, streptomisin, sülfadiazin, teikoplanin, trimetoprim/sülfametoksazol ve vankomisine karşı yüksek doğal direnç olduğu, penisilin ve ampisilin gibi pek çok hücre duvarı sentezi inhibitörüne karşı ise duyarlı oldukları belirtilmiştir (Danielsen ve Wind, 2003; Coppola ve ark., 2005; Shao ve ark., 2015).

Laktobasiller arasında plazmid bağlantılı antibiyotik direnci çok yaygın olmamasına rağmen, güvenlik önlemleri dikkate alınmalıdır (Ishiwa ve Iwata, 1980; Vescovo ve ark., 1982; Rinckel ve Savage, 1990). Örneğin; kuru fermente sosislerin üretimi için başlatıcı veya koruyucu kültür olarak kullanılan suşların güvenilirlik değerlendirmesinde, komensal veya patojen bakteriyel bulaşmaları önlemek için, seçilen suşlarda antibiyotik direnç genlerinin varlığını yok etmeleri esas alınır (EFSA, 2012; EFSA, 2013). Benzer şekilde suşlar, biyojenik aminler gibi diğer virülans faktörleri üretmemelidir 
(EFSA, 2011). Kuru fermente sosislerin üretimi için başlatıcı kültürler veya koruyucu kültürler olarak kullanılan bakteri, muhtemelen antibiyotik direnç genleri içerebilir ve bu da kommensal veya patojenik bakterilere aktarılabilir ve bu durum EFSA tarafından kabul edilmemiştir. Antimikrobiyal direnç Kalifiye Emniyet Varsayımları (KEV) listesinde bakteri türlerinin değerlendirilmesi ve eklenmesi için olası bir güvenlik kaygısı olarak ortaya çıkmıştır (EFSA, 2012). Kuru fermente edilmiş sosislerden izole edilen LAB'nin antibiyotik duyarlılığı genellikle Klinik ve Laboratuvar Standartları Enstitüsü yönergelerine göre yapılır (CLSI, 2013).

EFSA (2013) toplam olarak 35 Lactobacillus türünün KEV statüsüne sahip olduğunu düşünmektedir. Bu grupta L. sakei, L. curvatus, L. plantarum, L. fermentum, $L$. brevis, $L$. rhamnosus ve $L$. alimentarius gibi kuru fermente sosislerde de en çok tespit edilen türler bulunmaktadır. Lactobacillus türlerine ek olarak, diğer LAB türlerine de KEV statüsü verilmiştir. Bunlara Leuconostoc citreum, Lactococcus lactis, Leuconostoc mesenteroides ve Leuconostoc pseudomesenteroides, Pediococcus acidilactici, Pediococcus dextrinicus ve Pediococcus pentosaceus, ve Str. salivarius subsp. thermophilus (Str. thermophilus) türleri dahildir. Enterococcus faecium ise KEV listesinde önerilmemiştir (EFSA, 2013).

\section{Farklı Gıdalardan İzole Edilen LAB'nin Antibiyotik Direnç Profillerinin Belirlenmesi Üzerine Yapılan Bazı Araştırmalar}

LAB'nin antibiyotik profilleri için dirençli ve duyarlı suşların belirlenmesinde kullanılan antibiyotik sınır değerlerinin açıkça tanımlanması gerekmektedir. Doğal ve kazanılmış direnç arasındaki ayrım önemlidir. Bu durum farklı kaynaklardan izole edilen pek çok $L A B$ ve bifidobakteri türlerindeki antimikrobiyal direnç örneklerinin karşılaştırılmasını gerektirir. Antibiyotik sınır değerleri bakteri suşlarındaki kazanımış ve aktarılma riski taşıyan direncin tanımlanmasında önemlidir (Mathur ve Singh, 2005; Ammor ve ark., 2007).

LAB'nin antibiyotik dirençleriyle ilgili yapılan çalışmaların çoğu, gıda mikroorganizmaları arasında farklı bir yere sahip olan Enterococcus cinsinin üyeleri üzerine yoğunlaşmıştır (Clementi ve Aquilanti, 2011). Portekiz'deki süt ve peynir örneklerinden izole edilen enterokoklar gentamisin direnci açısından araştırılmıştır (de Fátima Silva Lopes ve ark., 2003). Enterokoklar, genelde düşük düzeyde gentamisine doğal dirençli olarak düşünülse de, pek çok süt ürünü izolatında yüksek oranda gentamisin direnci saptanmıştır. Çıtak ve ark. (2004) yaptıkları araştırmada, E. faecalis, E. faecium, E. durans, E. munditii, E. hirae türlerine ait izolatların çoğunun streptomisin, oksasilin, eritromisin ve vanko- misine karşı yüksek direnç gösterdiklerini bulmuşlardır. Araştırmacılar, peynirlerin üretimi ve işlenmesi sırasında sanitasyon koşullarının zayıf olduğunu ve bu durumun tüketiciler açısından önemli bir sağlık riski oluşturduğuna dikkat çekmişlerdir.

Aslım ve Beyatı (2004), Türkiye'de farklı köy ve kasabalardan toplanan yoğurt örneklerinden 34 adet Str. thermophilus suşu izole etmişlerdir. İzolatların vankomisin, tetrasiklin, kloramfenikol, eritromisin, sefalotin, ampisilin-sulbaktam, gentamisin ve penisilin G'ye karşı dirençliliklerini belirlemişlerdir. Str. thermophilus suşunun gentamisin ve penisiline karşı dirençlilik gösterdiği belirlenirken, suşların tetrasiklin ve kloramfenikole duyarlı olduğu bulunmuştur. Tatı (2009) tarafından yapılan çalışmada ise LAB izolasyonu için geleneksel olarak üretilen çeşitli süt ürünleri piyasadan temin edilmiştir. Analize alınan 20 yoğurt örneğinden 23 adet LAB izole edilmiş, suşlar vankomisin, siprofloksasin, gentamisin, eritromisin ve tetrasikline dirençli olarak bulunmuştur. Bu suşların \%30'unun tüm antibiyotiklere duyarlı oldukları belirlenmiştir. 15 beyaz peynir örneğinden 23 adet $L A B$ izole edilmiş ve bu suşların vankomisin, gentamisin, siprofloksasin, eritromisin, kloramfenikol ve rifampisine dirençli olduğu, \%28'inin ise test edilen tüm antibiyotiklere karşı duyarlı olduğu tespit edilmiştir. 10 tulum peyniri örneğinden 18 adet LAB izole edilmiş, suşlar vankomisin, siprofloksasin, gentamisin, eritromisin ve tetrasikline dirençli olarak bulunurken, \%28'i tüm antibiyotiklere duyarlılık göstermiştir. 3 çökelek örneğinden izole edilen 5 LAB'ye ait suşlar ise vankomisin, gentamisin, siprofloksasin ve eritromisine dirençli olarak bulunmuştur. Araştırmada 1 kefir örneğinden izole edilen 2 LAB suşlarının her ikisi de vankomisine dirençli bulunurken, suşlardan biri gentamisine, diğeri eritromisine dirençli olarak bulunmuştur. Analize alınan 1 kaymak örneğinden tek bir LAB izole edilmiştir ve test edilen tüm antibiyotiklere karşı duyarlıık tespit edilmiştir. Başyiğit Kılıç (2014) tarafından yapılan araştırmada, farklı illerin halk pazarlarından toplanmış, özellikle evlerde ve mandıralarda küçük ölçeklerde ve geleneksel yöntemlerle üretilmiş 51 adet beyaz peynir örneğinden izole edilen 51 adet LAB'nin antibiyotik duyarlıık profilleri incelenmiştir. Araştırmada incelenen izolatların antibiyotik duyarlılık sonuçları değerlendirildiğinde, izolatların genel olarak ampisiline, vankomisine, penisiline, gentamisine, kloramfenikole ve teikoplanine duyarlı oldukları, streptomisin ve siprofloksasine ise dirençli oldukları tespit edilmiştir. Özteber (2013)'in yaptığı bir çalışmada fermente süt ürünlerinden izole edilen $\mathrm{LAB}$ izolatlarında en yüksek direnç linkomisin (\%25.59) antibiyotiğine karşı bulunmuştur. Bu değeri sırasıyla tetrasiklin, meropenem, ampisilin, gentamisin, eritromisin, siprofloksasin, kloramfenikol ve vankomisin antibiyotikleri izlemektedir. 
Ouoba ve ark. (2008), Afrika ve Avrupa kökenli çeşitli LAB ve bifidobakterilerin antibiyotik dirençleri ve bu direncin in vitro transferi ile ilgili yaptığı çalışmada, Avrupa izolatlarında yüksek oranda fenotipik aminoglikozid direnci saptanmıştır. Egervarn ve ark. (2009)'nın yaptığı çalışmada ise; $L$. reuteri ve $L$. plantarum türlerinin karakterizasyonu yapılmış ve tetrasiklin, eritromisin, klindamisin ve kloramfenikol antibiyotikleri için minimum inhibisyon lonsantrasyonu (MIK) değerleri belirlenmiştir. 28 adet $L$. reuteri suşunun 24'ünde $\operatorname{tet}(\mathrm{W})$ geni ve yüksek tetrasiklin MiK değerleri bulunmuştur. Ayrıca altı suşun dördünde eritromisin için yüksek Mik değerleri ve erm(B), erm(C) ve erm(T) genleri belirlenmiştir. Bunun yanında iki $L$. plantarum suşunda da yüksek MiK değeri ve plazmidde kodlanan tet(M) geni bulunmuştur. Clementi ve Aquilanti (2011) inceledikleri LAB'nin bazı suşların tet(M) ve erm(T) genleri taşıdığı, ancak çiğ sütten yapılan peynirden izole edilen K214 suşunun en azından 3 farklı farklı plazmidde kodlanmış kloramfenikol, tetrasiklin ve streptomisin direnç geni taşıdığı belirtilmiştir. tet(S) geninin varlığı Leuconostoc citreum için de bildirilmiştir, erm(B) geni Pediococcus acidilacticinin üç suşunda tespit edilirken, yine aynı bakterinin bir izolatında aac (6')-aph (2") geni saptanmıştır.

Comunian ve ark. (2010) farklı coğrafi bölgelerden gelen İtalyan fermente ürünlerinden izole ettikleri $L$. paracasei 197 izolatının, tetrasiklin ve eritromisin duyarlılığını değerlendirmişlerdir. İzolatlar tür seviyesinde tanımlanarak genotipik olarak toplam 121 farklı suş tespit edilmiş ve bunların etken antibiyotiklere karşı direnci belirlenmiştir. Fenotipik olarak dirençli izolatlarda ermB, erm $C$ ve tetL, tet $M$, tetS, tet $W$ genlerinin varığı polimeraz zincir reaksiyonu ile araştırılmıştır. Test edilen 121 suştan \%77.7'sinin tetrasikline ve \%94.2'si eritromisine duyarlı bulunmuştur. Genel olarak, 27 suşun tetrasikline dirençli (TetR) ve bunlardan 7'sinin aynı zamanda eritromisine (ErmR) dirençli olduğu belirlenmiştir. Çalışmada L. paracaseinin tetrasiklin ve eritromisine karşı oldukça duyarlı olduğu doğrulanmıştır. Araştırmacılar $L$. paracasei izolatlarında tanımlanan genlerin yatay olarak diğer türlere transfer edilip edilmeyeceğini analiz etmek için ileri araştırmalara intiyaç duyulduğunu belirtmişlerdir.

Pan ve ark. (2011) 11 adet fermente Çin gıda örneğinden LAB izolasyonu yaparak kloramfenikol, kanamisin, tetrasiklin, siprofloksasin, ampisilin, klindamisin ve eritromisin olmak üzere klinik açıdan önemli 7 antibiyotiğe karşı direnci araştırmıştır. Direnç etkisi fermente sebzelere oranla, fermente sucuk ve sosislerde daha fazla bulunmuştur. Zhou ve ark. (2012), tarafından farklı bölgelerden alınan yoğurtlardan ampisilin, penisilin G, roksitromisin, kloramfenikol, tetrasiklin, klortetrasiklin, linkomisin, kanamisin, streptomisin, neomisin ve gentamisine duyarlı 43 LAB izole edilerek 18'inin L. delbru- eckii subsp. bulgaricus (L. bulgaricus) ve 25'inin Str. thermophilus olduğu tespit edilmiştir. Test edilen bakterilerin arasında dirençlilik dağılımı, 35 suşta ampisilin, kloramfenikol, klortetrasiklin, tetrasiklin, linkomisin, streptomisin, neomisin ve gentamisin olarak bulunmuştur. Bütün Str. thermophilus suşlarının penisilin $G$ ve roksitromisine duyarlı olduğu bulunmuştur. Buna karşın L. bulgaricus suşlarının penisilin $G$ ve roksitromisine sırasıyla \%23.5 ve \%64.7 oranında dirençli olduğu tespit edilmiştir. Ayrıca bütün Str. thermophilus ve $L$. bulgaricus suşları kanamisine dirençli bulunmuştur.

Thumu ve Halami (2012), farklı gıda örneklerinden eritromisine dirençli LAB'leri izole etmişlerdir. $E$. $d u$ rans, E. faecium, E. casseliflavus, Lc. lactis, L. salivarius, L. reuteri, L. plantarum, L. fermentum, P. pentosaceus ve $L e u$. mesenteroides türleri olarak tanımlanan 60 izolatın \%88'inde erm(B) geni tespit edilmiştir. Effluks $m s r(A)$ geni E. faecium, E. durans, Lc. lactis, E. casseliflavus, $P$. pentosaceus, $L c$. lactis ve $L$. fermentum izolatlarında tanımlanmıştır, ayrıca $m s r(A)$ geni için yapılan sekans analizi sonucunda $\operatorname{msr}(\mathrm{C})$ geniyle homoloji ortaya çıkmıştır. Lactobacillus türlerinde tetrasiklin $\operatorname{direnci} \operatorname{tet}(\mathrm{M}), \operatorname{tet}(\mathrm{W})$, $\operatorname{tet}(\mathrm{O})$, $\operatorname{tet}(\mathrm{K})$ ve tet $(\mathrm{L})$ genlerinin biri ya da bunların kombinasyonu ile oluşmakta olduğu belirlenmiştir. tet $(\mathrm{K})$ ve tetrasiklin effluks tet $(\mathrm{L})$ geni $P$. pentosaceus ve Enterococcus türlerinde bulunmuştur. Landeta ve ark. (2013) ise kuru kürlenmiş sosislerden izole ettikleri LAB içinden başlatıcı kültürler seçerek teknolojik ve güvenilirlikleri ile ilgili özellikleri analiz etmişlerdir. E. faecium antibiyotiklere karşı en dirençli, L. sakei suşları en duyarlı bulunmuştur. Virülans faktörleri ile ilgili olarak, analiz edilen E. faecium suşlarında sadece efa(A) geninin varlığı saptanmıştır.

Federici ve ark (2014), Orta İtalya'nın Marche Bölgesinde üretilen Ciauscolo'dan elde edilen LAB ve laboratuvarlarına ait LAB suşlarının antibiyotik dirençlilik özelliklerini incelemişlerdir. Suşlar değişken antibiyotik dirençleri göstermelerine rağmen, test edilen tüm antibiyotikler için genel olarak direnç seviyesi \%15'in üzerinde tespit edilmiştir. Bakterilerin \%88.09'u streptomisine ve \%16.67'si klindamisin'e dirençli bulunmuştur. Lactobacillus suşları streptomisin ve gentamisin gibi aminoglikozidlere karşı yüksek direnç göstermiştir. Laktobasiller özellikle klindamisin ve eritromisin için duyarlı bulunmuştur. Streptokoklar arasında, suşların çoğunda gentamisin ve kloramfenikole karşı direnç görülmüştür. Ampisiline dirençli olan tek suş Lactococcus spp. 35380-3'dir. Tüm Pediococcus suşları ampisilin, streptomisin ve tetrasikline dirençli iken, sadece bir suşun klindamisine ve üç suşun eritromisine duyarlı olduğu görülmüştür. İolatlar arasında direnç belirleyicileri erm(B) ve tet (M) genleri yalnızca gıda kaynaklı dokuz suşda ve laboratuvar koleksiyonuna ait bir LAB'de tet(L) bulunmuştur. Alp ve Öner (2014) yaptıkları çalış- 
mada ise çiğ sütten üretilen beyaz ve kaşar peynirlerden izole edilen ve tanımlanan 123 adet LAB'nin vankomisin, kloramfenikol, rifampisin, penisilin, tetrasiklin, eritromisin, novobiosin, oleandomisin, oksitetrasiklin nitrofurantoin, ampisilin, gentamisin ve siprofloksasin gibi 13 farklı antibiyotiğe karşı dirençli olduklarını belirlemişlerdir.

Singh ve ark. (2016) Hindistan'ın Allahabad kentinin yerel bölgelerinden aldıkları gıda örneklerinden 110 adet Lactobacillus izole ederek 61 izolatı L. acidophilus, L. fermentum, L. plantarum, $L$. casei ve $L$. rhamnosus olarak tanımlamışlardır. İolatların yaklaşık \%47,4'ü düşük ampisilin $(5 \mathrm{mg} / \mathrm{ml})$ ve streptomisin $(2.5 \mathrm{mg} / \mathrm{ml})$ konsantrasyonlarına dirençli bulunmuştur. Konsantrasyon her iki antibiyotik için $10 \mathrm{mg} / \mathrm{ml}$ 'ye yükseltildiğinde, izole edilen suşların duyarlı hale geldiği gözlenmiştir. İolatların yaklaşık \%44.2'sinin $10 \mathrm{mg} / \mathrm{ml}$ ampisilin ve streptomisine karşı oldukça hassas olduğu bulunmuştur. Bulguların, Belleti ve ark. (2009) tarafından daha önce bildirilen $L$. acidophilus ve $L$. plantarum suşlarının çoğunun ampisilin ve streptomisine duyarlı olduğu sonuçlarıyla uyumlu olduğu görülmüştür. Tigu ve ark. (2016) Datta ve Awaze isimli iki geleneksel fermente bal çeşidinden izole ettikleri 100 adet LAB izolatının kloramfenikol, klindamisin, eritromisin, tetrasiklin, gentamisin, ampisiline karşı duyarlı olduğunu bulmuşlardır. Penisiline on izolatta duyarlılık görülürken, vankomisine beş izolatta duyarlılık görülmüştür.

\section{SONUÇLAR}

Insan ömrünün uzunluğu ve kalitesi; beslenme alışkanlıklarındaki gelişmeler ve enfeksiyon hastalıklarına karşı antibiyotiklerin kullanılmasıyla oldukça artmıştır. Bununla birlikte, antibiyotik uygulamalarının altın çağı, zararlı mikroorganizmalar arasında direncin ortaya çıkması ve yayılması ile giderek kapanmaktadır. Yapılan çalışmalar antibiyotik kullanımının bilinçsiz ve olması gerekenden fazla olduğunu vurgulamaktadır. Fermente ve probiyotik gıdaların üretiminde kullanılan LAB'nin genellikle güvenli mikroorganizmalar oldukları düşünülse de, antibiyotik direnç geni bulundurmaları durumunda, bu genleri patojenlere veya florada bulunan diğer bakterilere aktarma intimalleri önemli bir tehdittir. Bu nedenle gıda sanayinde kullanılacak LAB'nin direnç genleri ve biyogüvenilirlik özellikler açısından incelenmeleri önemlidir. Yapılacak araştırmalarda, direnç geni taşıyan bakterilerin konjugasyon denemeleri ile bu özellikleri başka bakterilere transfer edebilme yetenekleri araştırılmalıdır. Ayrıca Avrupa'daki farklı kurumlar tarafından sürekli revize edilen raporların bilimsel yayınların, gıda ve yemlerden izole edilen mikroorganizmalarının antibiyotik direnci ile ilgili bilimsel araştırmaların takip edilmesi de oldukça önemlidir.

\section{KAYNAKLAR}

Akkan, G., (1997). Antibiyotiklerin sınıflandırılmaları. İ.Ü. Cerrahpaşa Tıp Fakültesi Sürekli Tıp Eğitimi Etkinlikleri, Pratikte Antibiyotik Kullanımı Sempozyumu (2-3 Mayıs). 53-62, İstanbul.

Alp, D., Öner, Z., (2014). Bazı laktik asit bakterilerinin antibiyotik dirençlilikleri ve aroma maddeleri oluşturma özelliklerinin belirlenmesi. Gıda, 39(6), 331-337.

Ammor, M.S., Florez, A. B., Mayo, B. (2007). Antibiotic resistance in non-enterococcal lactic acid bacteria and bifidobacteria. The International Journal of Food Microbiology, 24, 559-570.

Aslım, B., Beyatlı, Y. (2004). Antibiotic resistance and plasmid DNA contents of Streptococcus thermophilus strains isolated from Turkish yoghurts. The Journal of Food Science and Technology, 41, 18- 22.

Başyiğit Kılıç, G. (2014). Farklı peynir çeşitlerinden izole edilen laktik asit bakterilerinin tanımlanması ve süt endüstrisinde kullanımının araştırılması, TAGEM-11/ARGE/05 (2011-2013), Proje Raporu (basılmamış).

Belletti, N., Gatti, M., Bottari, B., Neviani, E., Tabanelli, G., Gardini, F. (2009). Antibiotic resistance of lactobacilli isolated from two Italian hard cheeses. Journal of Food Protection, 72(10), 2162-2169.

Billot-Klein, D., Gutmann, L., Sable, S., Guittet, E., van Heijenoort, J. (1994). Modification of peptidoglycan precursors is a common feature of the low-level vancomycin-resistant VANB-type Enterococcus D366 and of the naturally glycopeptide-resistant species Lactobacillus casei, Pediococcus pentosaceus, Leuconostoc mesenteroides and Enterococcus gallinarum. Journal of Bacteriology, 176(8), 2398-2405.

Charteris, W. P., Kelly, P. M., Morelli, L., Collins, J. K. (1998). Antibiotic susceptibility of potentially probiotic Lactobacillus species. Journal of Food Protection, 61, 1636-1643.

Clementi, F., Aquilanti, L. (2011). Recent investigations and updated criteria for the assessment of antibiotic resistance in food lactic acid bacteria. Anaerobe, 17, 394-398.

Clewell, D. B. (2014). Antibiotic resistance plasmids in bacteria. In Wiley Online Library. Retrieved from http://www.els.net/WileyCDA/ElsArticle/reflda0001491.html.

CLSI. 2013. Clinical and Laboratory Standards Institute. Performance standards for antimicrobial susceptibility testing. CLSI document M100-S23-Twenty third Informational supplement. CLSI, Wayne, Pennsylvania.

Comunian, R., Daga, E., Dupre, L., Paba, A., Devirgiliis, C., Piccioni, V., Perozzi, G., Zonenschain, D., Rebecchi, A., Morelli, L., De Lorentiis, A., Giraffa, G. (2010). Susceptibility to tetracycline and erythromycin of Lactobacillus paracasei Strains Isolated from Traditional Italian Fermented Foods. The International Journal of Food Microbiology, 138, 151156.

Coppola, R., Succi, M., Tremonte, P., Reale, A., Salzano, G., Sorrentino, E. (2005). Antibiotic susceptibility of Lactobacillus rhamnosus strains isolated from Parmigiano Reggiano cheese. Le. Lait, 85, 193-204.

Çataloluk, O., Göğebakan, B. (2004). Presence of drug resistance in Intestinal lactobacilli of dairy and human origin in Turkey. FEMS Microbiology Letters, 236, 7-12. 
Çıtak, S., Yücel, N., Orhan, S. (2004). Antibiotic resistance and incidence of Enterococcus species in Turkish White cheese. International Journal of Dairy Technology, 57, 2731.

Danielsen, M. (2002). Characterization of the tetracycline resistance plasmid pMD5057 from Lactobacillus plantarum 5057 reveals a composite structure. Plasmid, 48, 98103.

Danielsen, M., Wind, A. A. (2003). Susceptibility of Lactobacillus spp. to antimicrobial agents. International Journal of Food Microbiology, 82, 1-11.

EFSA. (2005). QPS. Qualified presumption of safety of microorganisms in food and feed. EFSA Scientific Colloquium Summary Report. European Food Safety AuthorityOctober 2005. Parma, Italy. ISBN: 92-9199-012-4, p. 143.

EFSA. (2007). Opinion of the scientific committe on a request from EFSA on the introduction of a qualified presumption of safety (QPS) approach for assessment of selected microorganisms referred to EFSA. EFSA Journal, 187, 1-16.

EFSA. (2011). EFSA panel on biological hazards (BIOHAZ); scientific opinion on scientific opinion on risk based control of biogenic amine formation in fermented foods. EFSA Journal, 9(10), 93 (2393).

EFSA. (2012). EFSA panel on additives and products or substances used in animal feed (FEEDAP). Guidance on the assessment of bacterial susceptibility to antimicrobials of human and veterinary importance. EFSA Journal, 10(6), 10 (2740).

EFSA. (2013). EFSA BIOHAZ panel (EFSA Panel on Biological Hazards). Scientific opinion on the maintenance of the list of QPS biological agents intentionally added to food and feed. EFSA Journal, 11(11),108 (3449).

Egervarn, M. (2009). Antibiotic resistance in Lactobacillus reuteri and Lactobacillus plantarum. Unpublished Ph. D. Dissertation. Swedish University of Agricultural Sciences, Dept. of Microbiology, Sweeden.

Eraksoy, H. (2011). Antibiyotik direnci ve direnç mekanizmaları. Türkiye Klinikleri J Inf Dis-Special Topics 4(1), 1-14.

Evren, M., Apan, M., Tutkun, E., Evren, S. (2011). Geleneksel fermente gıdalarda bulunan laktik asit bakterileri. Elektronik Mikrobiyoloji Dergisi TR, 9, 11-17.

Federici, S., Ciarrocchi, F., Campana, R., Ciandrini, E., Blasi, G., Baffone, W. (2014). Identification and functional traits of lactic acid bacteria isolated from Ciauscolo salami produced in Central Italy. Meat Science, 98(4), 575-584.

FEEDAP European Commision. (2005). Opinion of the FEEDAP panel on the updating of the criteria used in the assesment of bacteria for resistance to antibiotics of human or veterinary importance. EFSA Journal, 223, 1-12.

Göğebakan, B. (2003). Peynir ve insan örneklerinden elde edilen Lactobacillus cinsi bakterilerin antibiyotik dirençliliklerinin araştırılması. Gaziantep Üniversitesi Sağlık Bilimleri Enstitüsü Yüksek Lisans Tezi, Gaziantep, Türkiye, 77.

Hamilton-Miller, J. M. T., Shah, S. (1998). Vancomycin susceptibility as an aid to the identification of lactobacilli. Letters in Applied Microbiology, 26, 153-154.

Hummel, A., Holzapfel, W. H., Franz, C. M. A. P. (2007). Characterisation and transfer of antibiotic resistance genes from enterococci isolated from food. Systematic and Applied Microbiology, 30, 1-7.

Ishiwa, H., Iwata, M. (1980). Drug resistance plasmids in Lactobacillus fermentum. The Journal of General and Applied Microbiology, 26, 71-74.
Landeta, G., Curiel, J. A., Carrascosa, A. V., Muñoz, R., de las Rivas, B. (2013). Technological and safety properties of lactic acid bacteria isolated from Spanish dry-cured sausages. Meat Science, 95 (2), 272- 280.

Lin, C., Fung, Z. F., Wu, C. L., Chung, T. C. (1996). Molecular characterization of a plasmid-borne (pTC82) chloramphenicol resistance determinant (cat-TC) from Lactobacillus reuteri G4. Plasmid. 36, 116-124.

de Fátima Silva Lopes, M., Ribeiro, T., Martins, M. P., Tenreiro, R., Barreto Crespo, M. T. (2003). Gentamicin resistance in dairy and clinical enterococcal isolates and in reference strains. Journal of Antimicrobial Chemotherapy, 52, 214-219.

Madhavan, H. N., Sowmiy, M. (2011). Mechanisms of development of antibiotic resistance in bacteria among clinical specimens. Journal of Biological Sciences, 1, 42-48.

Mathur, T., Singh, R. (2005). Antibiotic resistance in food lactic acid bacteria- A Review The International Journal of Food Microbiology, 105, 281-295.

Munital, J. M., Arias, C. A. (2016). Mechanisms of antibiotic resistance. Microbiology Spectrum, 4(2)

Nicas, T. I., Cole, C. T., Preston, D. A., Schabel A. A., Nagarajan, R. (1989). Activity of glycopeptides against vancomycin-resistant Gram-positive bacteria. Journal of Antimicrobial Chemotherapy, 33, 1477-1481.

Ong, L., Shah, N. P. (2009). Probiotic cheddar cheese: Influence of ripening temperatures on survival of probiotic microorganisms, cheese composition and organic acid profiles. Journal of Food Science and Technology, 42, 12601268.

Ouoba, L.I., Lei, V., Jensen, L. B. (2008). Resistance of potential probiotic lactic acid bacteria and bifidobacteria of African and Europan origin to antimicrobials: Determination and transferability of the resistance genes to other bacteria. The International Journal of Food Microbiology, 121(2), 217-224.

Özteber, M. (2013). Fermente süt ürünlerinden izole edilen laktik asit bakterilerinin antibiyotik dirençliliklerinin fenotipik ve genotipik yöntemlerle belirlenmesi. Yüksek Lisans Tezi, Adnan Menderes Üniversitesi, Fen Bilimleri Enstitüsü, Aydın.

Pan, L., Hu, X., Wang, X. (2011). Assesment of antibiotic resistance of lactic acid bacteria in chinese fermented foods. Food Control, 22, 1316-1321.

Rinckel, L.A., Savage, D. C. (1990). Characterization of plasmids and plasmid-borne macrolide resistance from Lactobacillus sp. strain. Plasmid. 23, 119-125.

Sageman, A. (2015). Antibiotic Resistance Mechanisms, Problems, and Solutions. Honors Projects. 416. http://scholarworks.gvsu.edu/honorsprojects/416.

Sharma, P., Tomar, S. K., Goswami, P., Sangwan V., Singh R. (2014). Antibiotic resistance among commercially available probiotics- A Review. Food Research International, 57, 176-195.

Shao, Y., Zhang, W., Gou, H., Pan, L., Zhang, H., Sun, T. (2015). Comparative studies on antibiotic resistance in Lactobacillus casei and Lactobacillus plantarum. Food Control, 50, 250-258.

Singh, P., Saini, P., Sachan, S., Dubey, S. (2016). Characterization, antimicrobial activity and antibiotic susceptibility of lactic acid bacteria Isolated from food samples. International Journal of Current Microbiology and Applied Sciences, 5(7), 901-911. 
Swenson, J. M., Facklam, R. R., Thornsberry, C. (1990). Antimicrobial susceptibility of vancomycin-resistant Leuconostoc, Pediococcus and Lactobacillus species. Antimicrobial Agents and Chemotherapy, 34, 543-549.

Tatlı, D. (2009). Geleneksel süt Geleneksel süt ürünlerinden izole edilen laktik asit bakterilerinin antibiyotik dirençlerinin belirlenmesi. Çukurova Üniversitesi Fen Bilimleri Enstitüsü. Yüksek Lisans Tezi, Adana.

Thumu, S. C. R., Halami, P. M. (2012). Presence of erythromycin and tetracycline resistance genes in lactic acid bacteria from fermented foods of Indian origin. Antonie van Leeuwenhoek, 102, 541-551.

Tigu, F., Assefa, F., Mehari, T., Ashenafi, M. (2016). Probiotic property of lactic acid bacteria from traditional fermented condiments: Datta and Awaze. International Food Research Journal, 23(2), 770-776.

Tynkkynen, S., Singh, K. V., Varmanen, P. (1998). Vancomycin resistance factor of Lactobacillus rhamnosus $G G$ in relation to enterococcal vancomycin resistance genes. The International Journal of Food Microbiology, 41, 195-204
URL1, (2017). http://www.who.int/mediacentre/factsheets/antibioticresistance/en/.

URL2 (2010). http://www.cdc.gov/drugresistance/about.html. Erişim 27.04.2018.

Vescovo, M., Morelli, L., Bottazzi, V. (1982). Drug resistance plasmids in Lactobacillus acidophilus and Lactobacillus reuteri. Applied and Environmental Microbiology, 43, 5056.

Vudalı, E. Y., Kınıklı, S., Cesur, S. (2014). Antibiyotiklerin yan etkileri. Turkish Journal of Clinical Laboratory, 5, (2), 1827.

Yüce, A. (2001). Antimikrobik ilaçlara direnç kazanma mekanizmaları. Klinik Dergisi, 14(2), 41-46.

Zhou, Y., Fuentes-Hernandez, C., Shim, J., Meyer, J., Giordano, A. J., Li, H., Winget, P., Papadopoulos, T., Cheun, H., Kim, J., Fenoll, M., Dindar, A., Haske, W., Najafabadi, E., Khan, T. M., Sojoudi, H., Barlow, S., Graham, S., Brédas, J. L., Marder, S. R., Kahn, A., Kippelen, B. (2012). A universal method to produce low-work function electrodes for organic electronics. Science, 336(6079), 327-332. 